\title{
SPIRITUAL EXPERIENCE, DEPRESSION, AND QUALITY OF LIFE IN THE ELDERLY IN MOJOKERTO, EAST JAVA
}

\author{
Lilik Ma'rifatul Azizah \\ School of Health Sciences (STIKes) Bina Husada, Mojokerto
}

\begin{abstract}
BACKGROUND: Elderly experience physical infirmity, brain devolution, slow metabolic rate, slow cell replacement, which eventually have inadvertent impact on cognitive capability, emotional stability, and social interaction. These natural changes may cause depression in the elderly. Spiritual experience may improve coping strategy, lower depression, and enhance quality of life. This study aimed to estimate the relationship between spiritual experience, depression, and quality of life in the elderly.

SUBJECT AND METHODS: This was a cross sectional study, conducted in Mojokerto, East Java. A sample of 100 elderly was selected by random sampling from 18 villages in Mojokerto. The exogenous variable in this study was spiritual experience, which was measured by a set of questionnaire. The endogenous mediating variable was the rate of depression, which was measured by Geriatric Depression Scale (GDS). The quality of life in the elderly was measured by Index Barthel. Psychological wellbeing and social relationship were measured by a structured questionnaire. The relationships among variables were estimated using Structural Equation Model (SEM) run in AMOS.

RESULTS: The spiritual experience had negative effect on depression, and it was statistically significant $(\mathrm{p}=0.004)$. Larger spiritual experience reduced depression level. In turn depression level had negative effect on quality of life, and it was statistically significant $(\mathrm{p}=0.003)$. Deeper depression reduced quality of life.
\end{abstract}

CONCLUSION: Spiritual experience can reduce depression and enhance quality of life in the elderly.

Keywords: spiritual experience, depression, quality of life, elderly 